Article

\title{
Optimization and Modeling of Process Parameters in Multi-Hole Simultaneous Drilling Using Taguchi Method and Fuzzy Logic Approach
}

\author{
Muhammad Aamir ${ }^{1}$, Shanshan Tu ${ }^{2, *}$, Majid Tolouei-Rad ${ }^{1}$, Khaled Giasin ${ }^{3}$ and Ana Vafadar ${ }^{1}$ \\ 1 School of Engineering, Edith Cowan University, Joondalup, WA 6027, Australia; m.aamir@ecu.edu.au (M.A.); \\ m.rad@ecu.edu.au (M.T.-R.); a.vafadarshamasbi@ecu.edu.au (A.V.) \\ 2 Faculty of Information Technology, Beijing University of Technology, Beijing 100124, China \\ 3 School of Mechanical and Design Engineering, University of Portsmouth, Portsmouth PO1 3DJ, UK; \\ khaled.giasin@port.ac.uk \\ * Correspondence: sstu@bjut.edu.cn
}

Received: 25 December 2019; Accepted: 27 January 2020; Published: 3 February 2020

\begin{abstract}
In industries such as aerospace and automotive, drilling many holes is commonly required to assemble different structures where machined holes need to comply with tight geometric tolerances. Multi-spindle drilling using a poly-drill head is an industrial hole-making approach that allows drilling several holes simultaneously. Optimizing process parameters also improves machining processes. This work focuses on the optimization of drilling parameters and two drilling processes-namely, one-shot drilling and multi-hole drilling-using the Taguchi method. Analysis of variance and regression analysis was implemented to indicate the significance of drilling parameters and their impact on the measured responses i.e., surface roughness and hole size. From the Taguchi optimization, optimal drilling parameters were found to occur at a low cutting speed and feed rate using a poly-drill head. Furthermore, a fuzzy logic approach was employed to predict the surface roughness and hole size. It was found that the fuzzy measured values were in good agreement with the experimental values; therefore, the developed models can be effectively used to predict the surface roughness and hole size in multi-hole drilling. Moreover, confirmation tests were performed to validate that the Taguchi optimized levels and fuzzy developed models effectively represent the surface roughness and hole size.
\end{abstract}

Keywords: one-shot drilling; multi-hole drilling; hole quality; optimization; Taguchi method; fuzzy logic

\section{Introduction}

Conventional drilling is considered to be the most economical and efficient machining processes in the aerospace and automotive industries [1]. The most important characteristics of drilled-hole quality are surface roughness (SR) and the deviation of the hole size (HS) from its nominal diameter [2]. This is because aircrafts constantly operate under vibration/shock conditions where thousands of fastener holes in the fuselage skins are prone to fatigue [2]. Fatigue cracks normally initiate and propagate after the fastened holes create regions of concentrated stress; therefore, the reliability of aircraft structures depends on their fatigue life, which is directly related to hole quality [3]. In addition, the drilling process is normally amongst the last steps of final assembly of fabricating parts, where poor hole quality might lead to part rejection, which can become costly if optimum process parameters, tools, or drilling operations are not taken into consideration [4].

The Taguchi method is useful for determining the best combination of factors under desired experimental conditions [5]. The Taguchi method reduces a large number of experiments that could 
be required in traditional experiments when the number of process parameters increases [6]. In the Taguchi method, an orthogonal array is designed that studies the entire parameter space with a small number of experiments [7]. Another statistical method is the analysis of variance (ANOVA) which is used for the interpretation of experimental data [8]. The main purpose of ANOVA is the determination of the highest influence that each design parameters presents [9].

Recently, artificial intelligence techniques have been acknowledged as effective and alternative ways for modeling many engineering or other systems precisely [10]. One of these techniques is fuzzy logic, which works on mathematical theory combining multivalued logic and probability theory to overcome complex problems [11]. Fuzzy logic provides extra intelligence and practical means to problem-solving with powerful reasoning capabilities bounded by a minimum number of rules [12].

Multi-spindle drilling using a poly-drill head is used to produce a large number of holes simultaneously, aiming to increase the productivity of the machining process and reduce operation time, hence reducing the overall manufacturing costs $[13,14]$.

Machining parameters play a significant role in any drilling operation where optimal process parameters help in achieving high-quality holes [15]. Several researchers have focused on different methods for the optimization of machining processes, where some of the recent studies are summarized in Table 1.

Table 1. Summary of different optimization techniques used for predicting process parameters in previous machining studies.

\begin{tabular}{|c|c|c|c|c|c|}
\hline Process & Material & $\begin{array}{l}\text { Considered } \\
\text { Process } \\
\text { Parameters }\end{array}$ & Objectives & $\begin{array}{c}\text { Optimization/Prediction } \\
\text { Technique }\end{array}$ & Ref \\
\hline OSD & AISI 4140 steel & DG, CS, and FR & CYL, PER, CON & Taguchi, ANOVA & [16] \\
\hline OSD & CFRP & SS, FR, and D & TF, T, DL & $\begin{array}{c}\text { ANOVA analysis, } \\
\text { Fuzzy logic }\end{array}$ & [17] \\
\hline OSD & $\begin{array}{l}\text { Hybrid polymer } \\
\text { composites }\end{array}$ & SS, FR, and D & $\mathrm{TF}, \mathrm{T}, \mathrm{DL}$ & $\begin{array}{l}\text { Gray relational analysis, } \\
\text { regression, fuzzy logic, and } \\
\text { artificial neural network } \\
\text { models }\end{array}$ & [10] \\
\hline Milling & $\begin{array}{l}\text { hardened Steel } \\
\text { (steel 1.2738) }\end{array}$ & $\begin{array}{c}\text { CS, FR, radial } \\
\text { depth, and axial } \\
\text { depth }\end{array}$ & SR & $\begin{array}{l}\text { Taguchi optimization } \\
\text { technique, ANOVA, }\end{array}$ & [9] \\
\hline OSD & $\begin{array}{l}\mathrm{Al} 6063 / \mathrm{Al} 2 \mathrm{O} 3 / \mathrm{Gr} \\
\text { hybrid composite }\end{array}$ & $\begin{array}{l}\text { SS, FR, and wt \% } \\
\text { of alumina }\end{array}$ & SR & Taguchi method & [18] \\
\hline OSD & CFRP & SS, FR, and D & $\mathrm{TF}, \mathrm{T}, \mathrm{DL}$ & $\begin{array}{c}\text { Taguchi method, } \\
\text { Principal component } \\
\text { analysis, Fuzzy inference } \\
\text { system }\end{array}$ & [19] \\
\hline OSD & GFRP & $\begin{array}{l}\text { SS, FR, point } \\
\text { angle, and chisel } \\
\text { edge width }\end{array}$ & TF, T, SR, C & Taguchi, ANOVA & {$[8]$} \\
\hline OSD & Al 7075 & Tool, FR, and CS & TEMP & Taguchi method, ANOVA & [20] \\
\hline End milling & GRFP & SS, FR, and d & $\mathrm{TL}$ & Fuzzy logic & [21] \\
\hline Turning & CFRP & CS, feed, and d & SR & Fuzzy rule-based modeling & [22] \\
\hline OSD & Al-7075 & $\begin{array}{l}\text { CS, FR, and point } \\
\text { angle, }\end{array}$ & $\mathrm{H}, \mathrm{SR}$ & $\begin{array}{l}\text { Taguchi method and } \\
\text { response } \\
\text { surface methodology }\end{array}$ & [23] \\
\hline OSD & GFRP & SS, FR, and D & SR & Fuzzy logic and ANOVA & [11] \\
\hline OSD & Al 2024 & $\begin{array}{l}\text { Drilling depth, } \\
\text { FR, CS, and } \\
\text { drilling tool }\end{array}$ & $\begin{array}{l}\text { Diametral error, } \\
\text { SR }\end{array}$ & $\begin{array}{c}\text { Regression model, Taguchi } \\
\text { optimization method, } \\
\text { ANOVA }\end{array}$ & [2] \\
\hline
\end{tabular}

An overview of the recently cited papers in Table 1 shows the importance of the optimization and prediction of process parameters using statistical design tools and the fuzzy logic approach. Table 1 also shows that optimization processes are commonly used in machining studies to employ the correct analyses, and effectively present that results were statistically analyzed using either one-shot single drilling or any other machining process. Therefore, in this work, the Taguchi method for the optimization of process parameters in multi-hole drilling using a poly-drill head is employed and 
is compared against one-shot drilling to evaluate its impact on two-hole quality metric: SR and HS. In addition, ANOVA and regression analysis are used to check the model accuracy and the impact of drilling parameters, respectively on the hole quality. Furthermore, the fuzzy logic approach is implemented to measure the values of SR and HS, which are then compared with the experimental results. Finally, validation tests are carried out at the optimal levels of process parameters to verify Taguchi's method and the simulated values of fuzzy logic.

\section{Materials and Methods}

Aluminium alloys have a superior machinability index and are extensively used in various industries such as the aircraft, aerospace, marine, and automotive industries [23]. Therefore, an Aluminium 5083 (Al5083) plate with a thickness of $10 \mathrm{~mm}$ and a size of $150 \mathrm{~mm} \times 200 \mathrm{~mm}$ was used in this work. The tool material used was $6 \mathrm{~mm}$ uncoated high-speed steel (HSS) twist drills with a point angle of $118^{\circ}$ and a helix angle of $30^{\circ}$ for both one-shot drilling and multi-hole drilling. A new tool in each experiment was used to confirm the initial conditions of each drilling trials. Figure 1 shows different steps of the experimental procedure and verification approach.

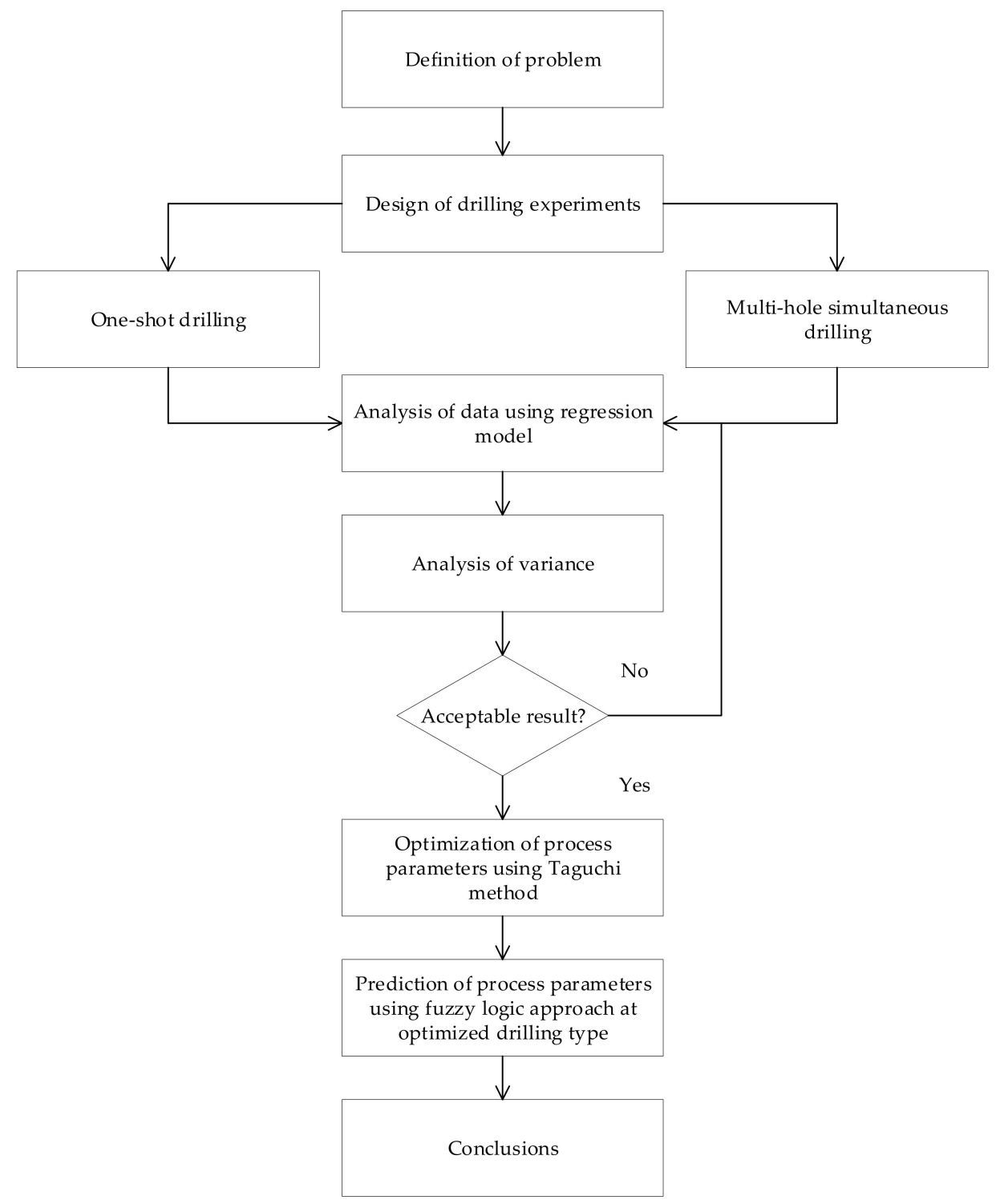

Figure 1. Layout for experimental procedure. 
The drilling experiments were carried under dry drilling conditions using a vertical turret milling machine. Figure 2 shows one-shot drilling and multi-spindle drilling. A SUNHER poly-drill head type $\mathrm{MH}$ 30/13 was used for drilling multi-holes simultaneously.
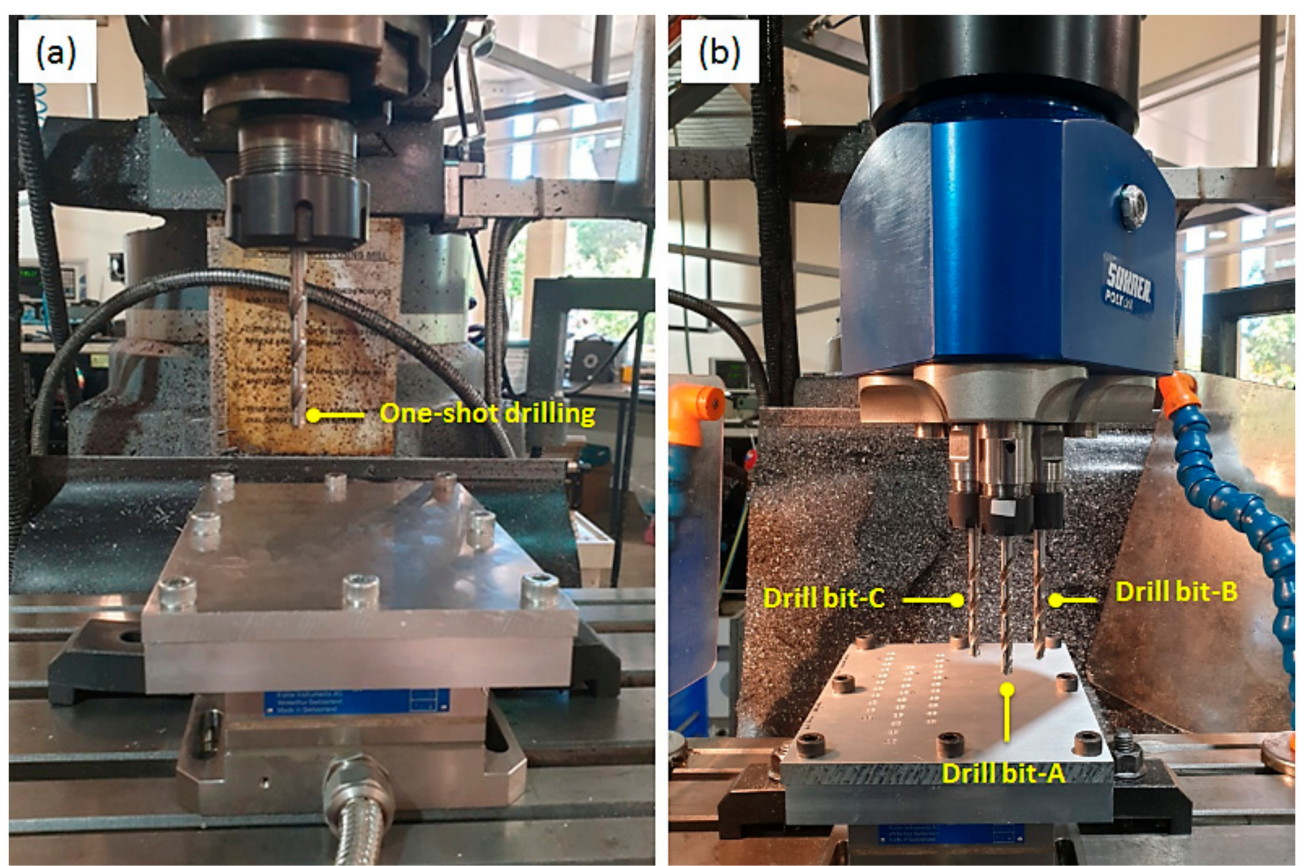

Figure 2. Setup of (a) one-shot drilling and (b) multi-spindle simultaneous drilling using a poly-drill head.

The surface roughness (SR) of each hole was measured using a roughness tester TR200 (PCWIprecision instrumentation, Australia) equipped with a diamond stylus having a $90^{\circ}$ cone angle and a 5 $\mu \mathrm{m}$ tip radius. The ROMER arm which is a balanced measuring instrument integrated with a portable coordinate measuring machine was used to measure the hole size (HS).

In this study, three drilling parameters including the cutting speed (CS), feed rate (FR), and drilling type (DT) were selected as control factors. A design of experiments (DoE) was employed to determine the relationship between controlled factors (input parameters) affecting the drilling process and the measured output parameters. The information obtained from DoE is needed to manage the drilling process inputs in order to optimize the measured outputs. Full factorial DoE was employed in the current study, which is practical when fewer than five factors are being investigated. The CS and FR were designed to have three levels, and DT has two levels, as given in Table 2. The drilling experiments were conducted according to $\mathrm{L}_{18}$ mixed orthogonal array including 18 runs corresponding to several tests for the Taguchi optimization method. The experimental layout with control factors is given in Table 3.

In Taguchi analysis, experimental values are then transformed into a signal-to-noise (S/N) ratio [8] where the term signal refers to the desired values (mean) and noise represent the undesired values (standard deviation) for the output characteristics [2]. In the analysis of the S/N ratio, the quality characteristics are [5] as follows.

Table 2. Process parameters and their levels.

\begin{tabular}{cccc}
\hline \multirow{2}{*}{ Levels } & \multicolumn{3}{c}{ Process Parameters } \\
\cline { 2 - 4 } & Drilling Type & Cutting Speed & Feed Rate \\
\hline 1 & One-shot drilling & 19 & 0.04 \\
2 & Multi-spindle drilling & 38 & 0.08 \\
3 & - & 57 & 0.14 \\
\hline
\end{tabular}


Table 3. Experimental layout with control factors.

\begin{tabular}{cccc}
\hline \multirow{2}{*}{ Experiment No. } & \multicolumn{3}{c}{ Control Factors } \\
\cline { 2 - 4 } & Drilling Type & Cutting Speed & Feed Rate \\
\hline 1 & & 19 & 0.04 \\
2 & & 19 & 0.08 \\
3 & One-shot drilling & 19 & 0.14 \\
4 & & 38 & 0.04 \\
5 & 38 & 0.08 \\
6 & & 38 & 0.14 \\
7 & 57 & 0.04 \\
8 & & 57 & 0.08 \\
9 & & 57 & 0.14 \\
10 & 19 & 0.04 \\
11 & & 19 & 0.08 \\
12 & 19 & 0.14 \\
13 & 38 & 0.04 \\
14 & & 38 & 0.08 \\
15 & Multi-spindle drilling & 38 & 0.14 \\
16 & & 57 & 0.04 \\
17 & & 57 & 0.08 \\
18 & & 57 & 0.14 \\
\hline
\end{tabular}

Higher the better:

$$
\mathrm{S} / \mathrm{N} \text { ratio }(\eta)=-10 \log _{10} \frac{1}{\mathrm{n}} \sum_{\mathrm{i}=1}^{\mathrm{n}} \frac{1}{\mathrm{y}_{\mathrm{i}}^{2}}
$$

Smaller the better:

$$
\mathrm{S} / \mathrm{N} \text { ratio }(\eta)=-10 \log _{10} \frac{1}{\mathrm{n}} \sum_{\mathrm{i}=1}^{\mathrm{n}} \mathrm{y}_{\mathrm{i}}^{2}
$$

where $y_{i}$ is the observed response value, and $n$ defines the number of replications.

Nominal the best:

$$
\mathrm{S} / \mathrm{N} \text { ratio }(\eta)=-10 \log _{10} \frac{\mu^{2}}{\sigma^{2}}
$$

where $\mu=$ mean and $\sigma=$ variance.

In the current work, the smaller the better is used to analyze and give the optimal values for the output characteristics i.e., SR and HS. Therefore, optimization of the process parameters was evaluated using the Taguchi method. Furthermore, regression analysis was carried out to correlate between the process parameters and the responses to check the closeness of the developed model with respect to experimental values of SR and HS. Moreover, ANOVA was used to determine the percentage contribution of process parameters on the output response. Finally, fuzzy logic based on Mamdani's fuzzy inference method was used to simulate the experimental values of the optimal drilling type.

\section{Results and Discussion}

\subsection{Regression Analysis}

In machining processes, regression analysis used to analyze and formulate the correlation between the process parameters and the responses [24]. In this study, the process parameters are the cutting speed (CS), feed rate (FR), and drilling type (DT), where the responses are the surface roughness (SR) and hole size (HS). Therefore, a linear regression model is used to check if the data of SR and HS signify a fitness characteristic. The regression model obtained in this work is given below:

$$
\begin{gathered}
\mathrm{SR}=\beta_{0}+\beta_{1}(\mathrm{DT})+\beta_{2}(\mathrm{CS})+\beta_{3}(\mathrm{FR})+\varepsilon \\
\mathrm{SR}=2.728-0.401 \mathrm{DT}+0.675 \mathrm{CS}+0.541 \mathrm{FR}+\varepsilon
\end{gathered}
$$




$$
\begin{gathered}
R^{2}=83.89 \% \\
\text { HS }=\beta_{0}+\beta_{1}(\mathrm{DT})+\beta_{2}(\mathrm{CS})+\beta_{3}(\mathrm{FR})+\varepsilon \\
\mathrm{HS}=6.01961-0.00167 \mathrm{DT}+0.007083 \mathrm{CS}+0.010593 \mathrm{FR}+\varepsilon \\
\mathrm{R}^{2}=95.09 \%
\end{gathered}
$$

where $\beta_{0}$ is the constant value when the predictor variables i.e., DT, CS, and FR are zero, $\beta_{1}+\beta_{2}$ $+\beta_{3}+\beta_{4}+\ldots+\beta n$ are the coefficients or estimates of the process parameters, and $\varepsilon$ is the error. $\mathrm{R}^{2}$ indicates the effectiveness of the developed model. The value equal to 1 shows that the model is $100 \%$ effective [25]. Therefore, the larger values of $\mathrm{R}^{2}$ are always desirable [26]. In the current study, the values of $\mathrm{R}^{2}$ are more than $80 \%$, which indicates that the models are effective in predicting the responses with respect to the machining variables. Figure 3 shows the normal probability plots of the residuals for a predicted response for SR and HS, respectively. Figure 3 also shows that the proposed models are satisfactory as all the residuals follow almost the same pattern of the straight line, which has also been reported by Davidson et al. [27] and Vankanti and Ganta [8]. Therefore, for the selection of process parameters in drilling aluminum, this work will be useful for reducing SR and the deviation of HS from its nominal value.

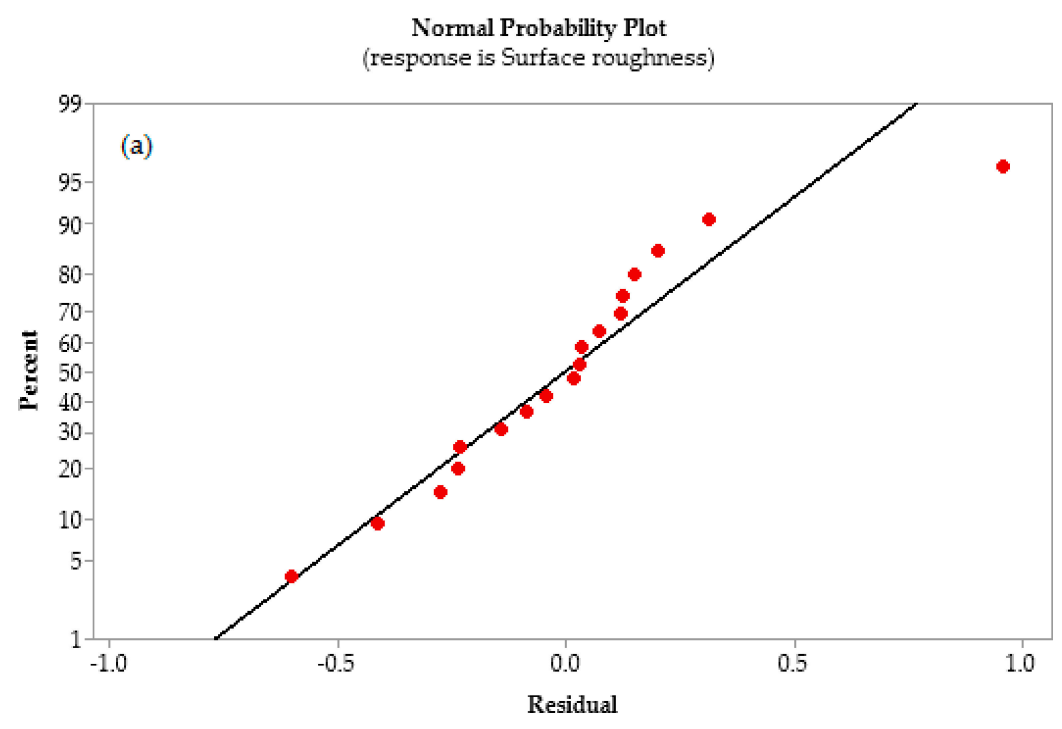

Normal Probability Plot (response is Hole size)

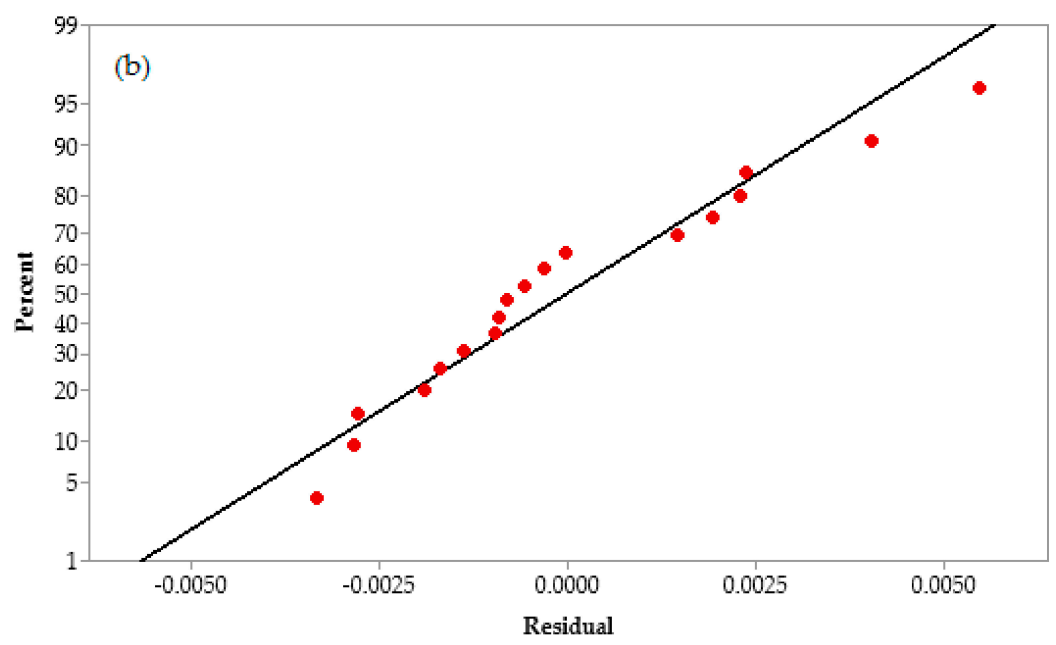

Figure 3. Normal probability plots of residuals for (a) surface roughness and (b) hole size. 


\subsection{Optimization of Drilling Conditions Using Taguchi Analysis}

As mentioned above, the optimization of drilling parameters in this work is done using Taguchi analysis for better hole quality. Therefore, after a set of experiments given by orthogonal array used in data analysis, the experimental results are then transformed into a $\mathrm{S} / \mathrm{N}$ ratio, and the smaller the better is used to determine the quality characteristics, as given in Equation (2) [5]. The orthogonal array with control factors, experimental results, and the respective $\mathrm{S} / \mathrm{N}$ ratio values are displayed in Table 4 .

Table 4. Experimental results according to orthogonal array with signal-to-noise $(\mathrm{S} / \mathrm{N})$ ratio.

\begin{tabular}{cccccccc}
\hline \multirow{2}{*}{ Trial No. } & \multicolumn{2}{c}{ Orthogonal Array with Control Factors } & \multicolumn{2}{c}{ Experimental Results } & \multicolumn{2}{c}{ S/N Ratio } \\
\cline { 2 - 8 } & $\begin{array}{c}\text { Drilling } \\
\text { Type }\end{array}$ & $\begin{array}{c}\text { Cutting } \\
\text { Speed }\end{array}$ & Feed Rate & $\begin{array}{c}\text { Surface } \\
\text { Roughness }\end{array}$ & Hole Size & $\begin{array}{c}\text { Surface } \\
\text { Roughness }\end{array}$ & Hole Size \\
\hline 1 & 1 & 1 & 1 & 3.561 & 6.040 & -11.030 & -15.620 \\
2 & 1 & 1 & 2 & 4.209 & 6.048 & -12.483 & -15.632 \\
3 & 1 & 1 & 3 & 4.657 & 6.056 & -13.362 & -15.644 \\
4 & 1 & 2 & 1 & 4.422 & 6.043 & -12.912 & -15.625 \\
5 & 1 & 2 & 2 & 4.522 & 6.052 & -13.107 & -15.638 \\
6 & 1 & 2 & 3 & 4.699 & 6.062 & -13.441 & -15.652 \\
7 & 1 & 3 & 1 & 4.808 & 6.047 & -13.639 & -15.631 \\
8 & 1 & 3 & 2 & 5.022 & 6.059 & -14.017 & -15.648 \\
9 & 1 & 3 & 3 & 6.933 & 6.073 & -16.818 & -15.669 \\
10 & 2 & 1 & 1 & 3.457 & 6.036 & -10.775 & -15.615 \\
11 & 2 & 1 & 2 & 3.718 & 6.044 & -11.405 & -15.627 \\
12 & 2 & 1 & 3 & 4.344 & 6.054 & -12.757 & -15.641 \\
13 & 2 & 2 & 1 & 3.676 & 6.039 & -11.307 & -15.620 \\
14 & 2 & 2 & 2 & 4.126 & 6.049 & -12.311 & -15.633 \\
15 & 2 & 2 & 3 & 4.626 & 6.059 & -13.304 & -15.648 \\
16 & 2 & 3 & 2 & 4.566 & 6.048 & -13.191 & -15.632 \\
17 & 2 & 3 & 3 & 5.990 & 6.061 & -13.961 & -15.651 \\
18 & 2 & 3 & 6.724 & 6.075 & -15.154 & -15.671 \\
\hline
\end{tabular}

Cutting speed (m/min), Feed rate $(\mathrm{mm} / \mathrm{rev})$, Surface roughness $(\mu \mathrm{m})$, Hole size $(\mathrm{mm})$.

One of the major characteristics of any machining process is the improvement of SR. SR shows irregularities in the surface of any workpiece due to machining operations [28]. A machined part with high SR results in excessive wear, fatigue, lower material ability to resist corrosion, and lower product performance [29]. SR might be affected by the drilling parameters, tool geometry, and relative vibration induced by the tool on the workpiece. Therefore, measuring SR is important for determining the quality of holes [30].

Table 5 and 6 show the average response values and S/N ratio values of SR and HS, respectively. Further, the $\mathrm{S} / \mathrm{N}$ ratio response graph for the $\mathrm{SR}$ and $\mathrm{HS}$ are shown in Figure 4. According to Yang and Tarng [7], an S/N ratio with higher values leads to better performance, irrespective of the category of the quality characteristic. Therefore, the level of a factor with the highest $\mathrm{S} / \mathrm{N}$ ratio is the optimum level. As evident in Table 5, the optimal SR is obtained at DT level 2, CS level 1, and FR level 1. This shows that at lower drilling parameters, multi-spindle drilling using a poly-drill head gives better SR. Lower CS and FR are also recommended by Giasin et al. [31], as higher CS might cause more vibration and chatter, which reduces the surface quality. Furthermore, a higher FR increases the chip thickness, which might also result in a higher SR of holes [32].

Table 5. Average response values and $\mathrm{S} / \mathrm{N}$ ratios for surface roughness.

\begin{tabular}{|c|c|c|c|c|c|c|}
\hline \multirow{3}{*}{ Level } & \multicolumn{6}{|c|}{ Surface Roughness } \\
\hline & \multicolumn{3}{|c|}{ Average Response Values } & \multicolumn{3}{|c|}{ S/N Ratio Response Values } \\
\hline & Drilling Type & $\begin{array}{l}\text { Cutting } \\
\text { Speed }\end{array}$ & Feed Rate & Drilling Type & $\begin{array}{l}\text { Cutting } \\
\text { Speed }\end{array}$ & Feed Rate \\
\hline 1 & 4.759 & $3.991^{\mathrm{a}}$ & $4.082^{a}$ & -13.423 & $-11.969^{a}$ & $-12.142^{a}$ \\
\hline 2 & $4.358^{a}$ & 4.345 & 4.431 & $-12.685^{a}$ & -12.730 & -12.881 \\
\hline 3 & - & 5.340 & 5.164 & - & -14.463 & -14.139 \\
\hline
\end{tabular}


(a) Main Effects Plot for SN ratios Data Means

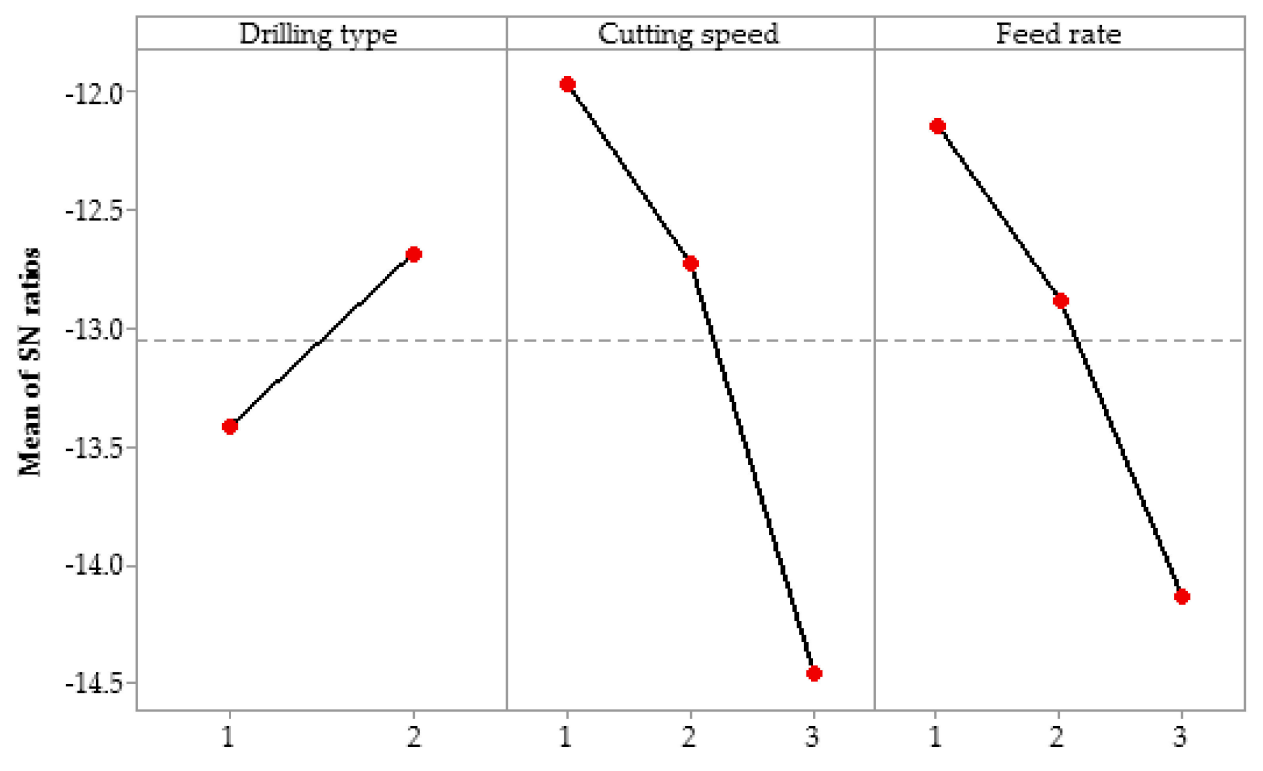

(b) Main Effects Plot for SN ratios Data Means

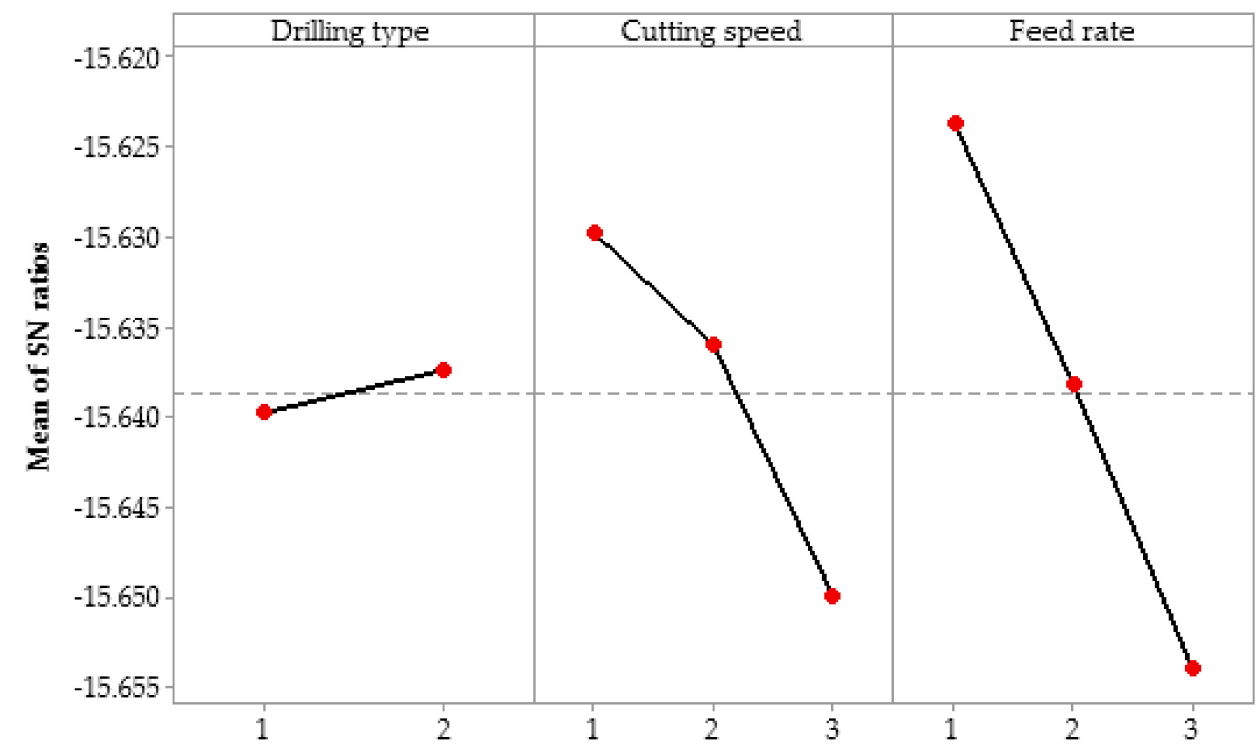

Figure 4. The effect of drilling parameters on (a) surface roughness and (b) hole size.

As mentioned earlier, all the drilling tools used in this study have a $6 \mathrm{~mm}$ diameter. Therefore, it is important to check if there is any deviation from the nominal size. Kurt et al. [29] reported in their studies that HS is also influenced by drilling parameters, where the hole diameter may increase from the nominal size. The reason for this was attributed to the fact that at high drilling parameters, there are higher chances of vibration due to the dynamic behaviour of the tool. Furthermore, Roukema and Altintas [33] have shown that there is an increased possibility of temperature in the tool and workpiece at high drilling parameters, which could adversely affect the drilled-holes and hinder chip evacuation and thus affect the HS [29]. Therefore, the selection of optimal drilling parameters is necessary for the measurement of HS. From Table 6 and Figure 4, the optimum conditions for HS can be selected. The analysis of $\mathrm{S} / \mathrm{N}$ ratio shows that the poly-drill head also performs better than one-shot drilling, as the best combination of parameters can be obtained at DT level 2, CS level 1, and FR level 1. 
Table 6. Average response values and $\mathrm{S} / \mathrm{N}$ ratios for hole size.

\begin{tabular}{|c|c|c|c|c|c|c|}
\hline \multirow{3}{*}{ Level } & \multicolumn{6}{|c|}{ Hole Size } \\
\hline & \multicolumn{3}{|c|}{ Average Response Values } & \multicolumn{3}{|c|}{ S/N Ratio Response Values } \\
\hline & Drilling Type & Cutting Speed & Feed Rate & Drilling Type & Cutting Speed & Feed Rate \\
\hline 1 & 6.053 & $6.046^{a}$ & $6.042^{a}$ & -15.640 & $-15.630^{a}$ & $-15.624^{a}$ \\
\hline 2 & $6.052^{a}$ & 6.051 & 6.052 & $-15.637^{a}$ & -15.636 & -15.638 \\
\hline 3 & - & 6.060 & 6.063 & - & -15.650 & -15.654 \\
\hline
\end{tabular}

Lower FR facilitated the slower insertion of the tool, which allowed a stable and jerk-free performance as the cutting edges of the tool removed the material with smaller chip thickness; consequently, the HS shows less dimensional error [34]. Furthermore, at higher CS, chatter and drilling temperature appeared to be more, which might affect the size of the hole [29]. Therefore, it can be concluded that lower FR is recommended for lower SR and better dimensional accuracy. However, while a lower FR affects productivity, a poly-drill head gave three holes at the same drilling time, which would help in acquiring good productivity even when using a lower FR.

\subsection{Prediction of Surface Roughness and Hole Size at Optimal Levels}

The values of SR and HS at their optimal level of process parameters can be predicted as follows. The predicted mean at the optimal process parameters:

$$
\begin{aligned}
& \mathrm{SR}=(\text { Level })_{2}+(\text { Level })_{1}+(\text { Level })_{1}-2(\mathrm{Y})=4.358+3.991+4.082-2(4.559)=3.313 \\
& \mathrm{HS}=(\text { Level })_{2}+(\text { Level })_{1}+(\text { Level })_{1}-2(\mathrm{Y})=6.052+6.046+6.042-2(6.052)=6.035
\end{aligned}
$$

where (Level) $)_{2}$, (Level $)_{1}$, and (Level $)_{1}$ are the optimal levels of SR and HS obtained from Tables 5 and 6, respectively. $\mathrm{Y}$ is the overall mean of experimental values calculated from Table 4. Similarly, the corresponding $\mathrm{S} / \mathrm{N}$ ratio can be calculated to check whether the $\mathrm{SR}$ and $\mathrm{HS}$ values are acceptable.

The predicted $\mathrm{S} / \mathrm{N}$ ratio (maximum):

$$
\begin{aligned}
& \mathrm{SR}=(\mathrm{S} / \mathrm{N})_{2}+(\mathrm{S} / \mathrm{N})_{1}+(\mathrm{S} / \mathrm{N})_{1}-2(\mathrm{~S} / \mathrm{N})_{\mathrm{m}}=(-12.685)+(-11.969)+(-12.142)-2(-13.054)=-10.688 \\
& \mathrm{HS}=(\mathrm{S} / \mathrm{N})_{2}+(\mathrm{S} / \mathrm{N})_{1}+(\mathrm{S} / \mathrm{N})_{1}-2(\mathrm{~S} / \mathrm{N})_{\mathrm{m}}=(-15.637)+(-15.630)+(-15.624)-2(-15.639)=-15.614
\end{aligned}
$$

where $(\mathrm{S} / \mathrm{N})_{2},(\mathrm{~S} / \mathrm{N})_{1}$, and $(\mathrm{S} / \mathrm{N})_{1}$, are the maximum values of $\mathrm{S} / \mathrm{N}$ ratios of $\mathrm{SR}$ and $\mathrm{HS}$ at the optimal levels obtained from Tables 5 and 6 , respectively. $(\mathrm{S} / \mathrm{N})_{\mathrm{m}}$ is the overall mean of $\mathrm{S} / \mathrm{N}$ ratios calculated from Table 4.

\subsection{Analysis of Variance}

ANOVA has been applied in this study to measure the importance of each of the process parameters on SR and HS. Tables 7 and 8 show the ANOVA results for the SR and HS, respectively. The percent contribution in ANOVA is used to describe how much influence each process parameters has on the output responses. The P-value can confirm the effect of process parameters on responses and shows that values less than 0.05 have no effect [35]. Another statistical tool is F-value, which is used to check the design parameters with a significant impact on the quality characteristic [2]. The confidence interval chosen in this study is $95 \%(\alpha=0.05)$.

Accordingly, Table 7 shows that the statistical influences of CS and FR on SR were $40.16 \%$ and $25.02 \%$, respectively. This shows that the CS has more impact on hole roughness than the FR. Similar findings were also reported by Kilickap [23] when drilling aluminium alloys. However, in the case of HS, the influence of FR was more than the CS value given in Table 8. The percentage contribution of FR is $61.31 \%$, which is more than the contribution of CS with a statistical significance of $28.72 \%$. 
Table 7. ANOVA for surface roughness.

\begin{tabular}{|c|c|c|c|c|c|c|c|}
\hline Source & $\begin{array}{l}\text { Degrees of } \\
\text { Freedom }\end{array}$ & $\begin{array}{l}\text { Sequential } \\
\text { Sum } \\
\text { of Squares }\end{array}$ & Contribution & $\begin{array}{l}\text { Adjusted } \\
\text { Sum } \\
\text { of Squares }\end{array}$ & $\begin{array}{l}\text { Adjusted } \\
\text { Mean } \\
\text { Square }\end{array}$ & F-Value & P-Value \\
\hline Model & 19 & 36.0261 & $82.08 \%$ & 36.0261 & 1.89611 & 8.2 & 0 \\
\hline CS & 2 & 17.6251 & $40.16 \%$ & 17.6251 & 8.81254 & 38.09 & 0 \\
\hline FR & 2 & 10.9826 & $25.02 \%$ & 10.9826 & 5.49129 & 23.74 & 0 \\
\hline DT & 1 & 2.1673 & $4.94 \%$ & 2.1673 & 2.16731 & 9.37 & 0.004 \\
\hline $\begin{array}{c}\text { 2-Way } \\
\text { Interactions }\end{array}$ & 8 & 2.4065 & $5.48 \%$ & 2.4065 & 0.30081 & 1.3 & 0.276 \\
\hline CS $x$ FR & 4 & 2.2008 & $5.01 \%$ & 2.2008 & 0.55019 & 2.38 & 0.071 \\
\hline $\mathrm{CS} \times \mathrm{DT}$ & 2 & 0.0825 & $0.19 \%$ & 0.0825 & 0.04126 & 0.18 & 0.837 \\
\hline $\mathrm{FR} \times \mathrm{DT}$ & 2 & 0.1232 & $0.28 \%$ & 0.1232 & 0.06159 & 0.27 & 0.768 \\
\hline $\begin{array}{c}\text { 3-Way } \\
\text { Interactions }\end{array}$ & 4 & 1.5096 & $3.44 \%$ & 1.5096 & 0.3774 & 1.63 & 0.189 \\
\hline $\begin{array}{c}\mathrm{CS} \times \mathrm{FR} x \\
\mathrm{DT}\end{array}$ & 4 & 1.5096 & $3.44 \%$ & 1.5096 & 0.3774 & 1.63 & 0.189 \\
\hline Error & 34 & 7.8658 & $17.92 \%$ & 7.8658 & 0.23135 & - & - \\
\hline Total & 53 & 43.8919 & $100.00 \%$ & - & - & - & - \\
\hline
\end{tabular}

Table 8. ANOVA for hole size.

\begin{tabular}{|c|c|c|c|c|c|c|c|}
\hline Source & $\begin{array}{l}\text { Degrees of } \\
\text { Freedom }\end{array}$ & $\begin{array}{l}\text { Sequential } \\
\text { Sum } \\
\text { of Squares }\end{array}$ & Contribution & $\begin{array}{l}\text { Adjusted } \\
\text { Sum } \\
\text { of Squares }\end{array}$ & $\begin{array}{l}\text { Adjusted } \\
\text { Mean } \\
\text { Square }\end{array}$ & F-Value & P-Value \\
\hline Model & 19 & 0.00622 & $94.34 \%$ & 0.00622 & 0.000327 & 29.84 & 0 \\
\hline CS & 2 & 0.001893 & $28.72 \%$ & 0.001893 & 0.000947 & 86.31 & 0 \\
\hline FR & 2 & 0.004042 & $61.31 \%$ & 0.004042 & 0.002021 & 184.24 & 0 \\
\hline DT & 1 & 0.000037 & $0.57 \%$ & 0.000037 & 0.000037 & 3.42 & 0.073 \\
\hline $\begin{array}{c}\text { 2-Way } \\
\text { Interactions }\end{array}$ & 8 & 0.000211 & $3.21 \%$ & 0.000211 & 0.000026 & 2.41 & 0.035 \\
\hline $\mathrm{CS} \times \mathrm{FR}$ & 4 & 0.000148 & $2.24 \%$ & 0.000148 & 0.000037 & 3.37 & 0.02 \\
\hline $\mathrm{CS} \times \mathrm{DT}$ & 2 & 0.000061 & $0.93 \%$ & 0.000061 & 0.00003 & 2.78 & 0.076 \\
\hline $\mathrm{FR} \times \mathrm{DT}$ & 2 & 0.000002 & $0.04 \%$ & 0.000002 & 0.000001 & 0.11 & 0.896 \\
\hline $\begin{array}{c}\text { 3-Way } \\
\text { Interactions }\end{array}$ & 4 & 0.000003 & $0.04 \%$ & 0.000003 & 0.000001 & 0.06 & 0.992 \\
\hline $\begin{array}{c}\mathrm{CS} \times \mathrm{FR} \times \\
\mathrm{DT}\end{array}$ & 4 & 0.000003 & $0.04 \%$ & 0.000003 & 0.000001 & 0.06 & 0.992 \\
\hline Error & 34 & 0.000373 & $5.66 \%$ & 0.000373 & 0.000011 & - & - \\
\hline Total & 53 & 0.006593 & $100 \%$ & - & - & - & - \\
\hline
\end{tabular}

\subsection{Fuzzy Modeling for Surface Roughness and Hole Size}

From the aforesaid Taguchi analysis, it is apparent the multi-hole drilling using a poly-drill head gives better SR and HS than those of one-shot drilling. Therefore, the experimental data of the poly-drill head are used for the fuzzy-based algorithm to predict SR and HS at different process parameters. In this regard, a conceptual framework based on the fuzzy logic algorithm is designed in $M A T L A B \otimes(R 2018 b)$ and is illustrated in Figure 5.

The fuzzy modeling is comprised of three steps that include the fuzzification process, rule framing process, and defuzzification. In the fuzzification process, with the help of the membership definition, each factor is treated as a well-defined numeric value. In the second stage, rules are designed by the combination of parameters using logical operators. Finally, defuzzification is done in which all membership degrees are made into a quantifiable value by combining the outputs of the framed rules [36].

CS and FR are taken as input in the fuzzy inference system where the SR and HS are considered as output. A fuzzy-based rule is defined that predicts SR and HS in the fuzzy domain, and the fuzzy interference engine is considered as "Mamdani". Mamdani shows relatively better results [37]. Therefore, in modeling the algorithm, the outputs of the system are calculated based on the centroid method, and Mamdani implication is used for defuzzification. A triangular membership function (MF) is considered in this study. In the developed algorithm, the input and output variables are fuzzified into nine fuzzy sets: very very low (VVL), very low (VL), low (L), moderately low (ML), medium $(\mathrm{M})$, moderately high $(\mathrm{MH})$, high $(\mathrm{H})$, very high $(\mathrm{VH})$, and very very high $(\mathrm{VVH})$. The associated MFs 
as input variables and output variables are shown in Figure 6, and the detailed parameters of fuzzy inference system with the triangular MFs are given in Table 9.

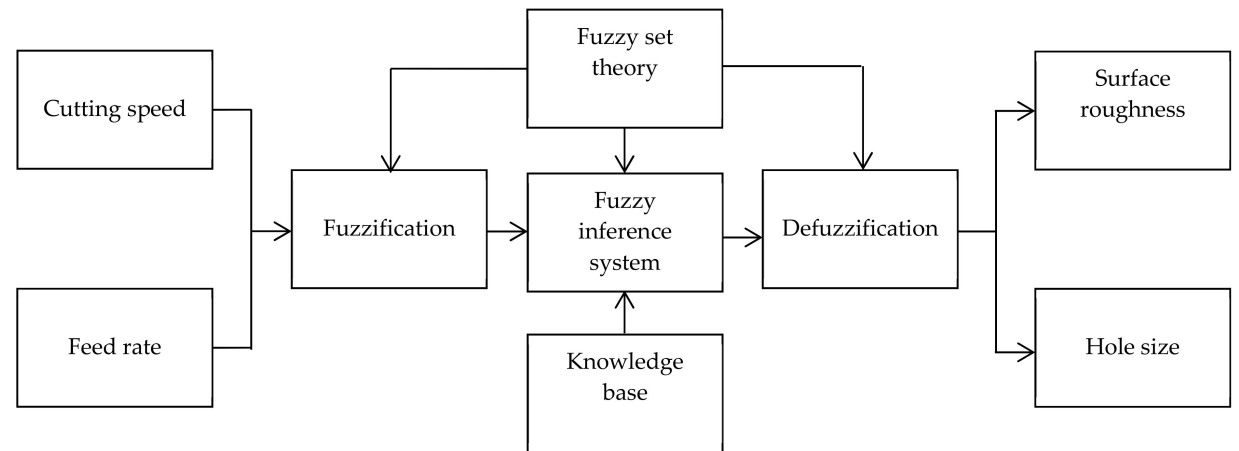

Figure 5. Schematic diagram of the developed algorithm.
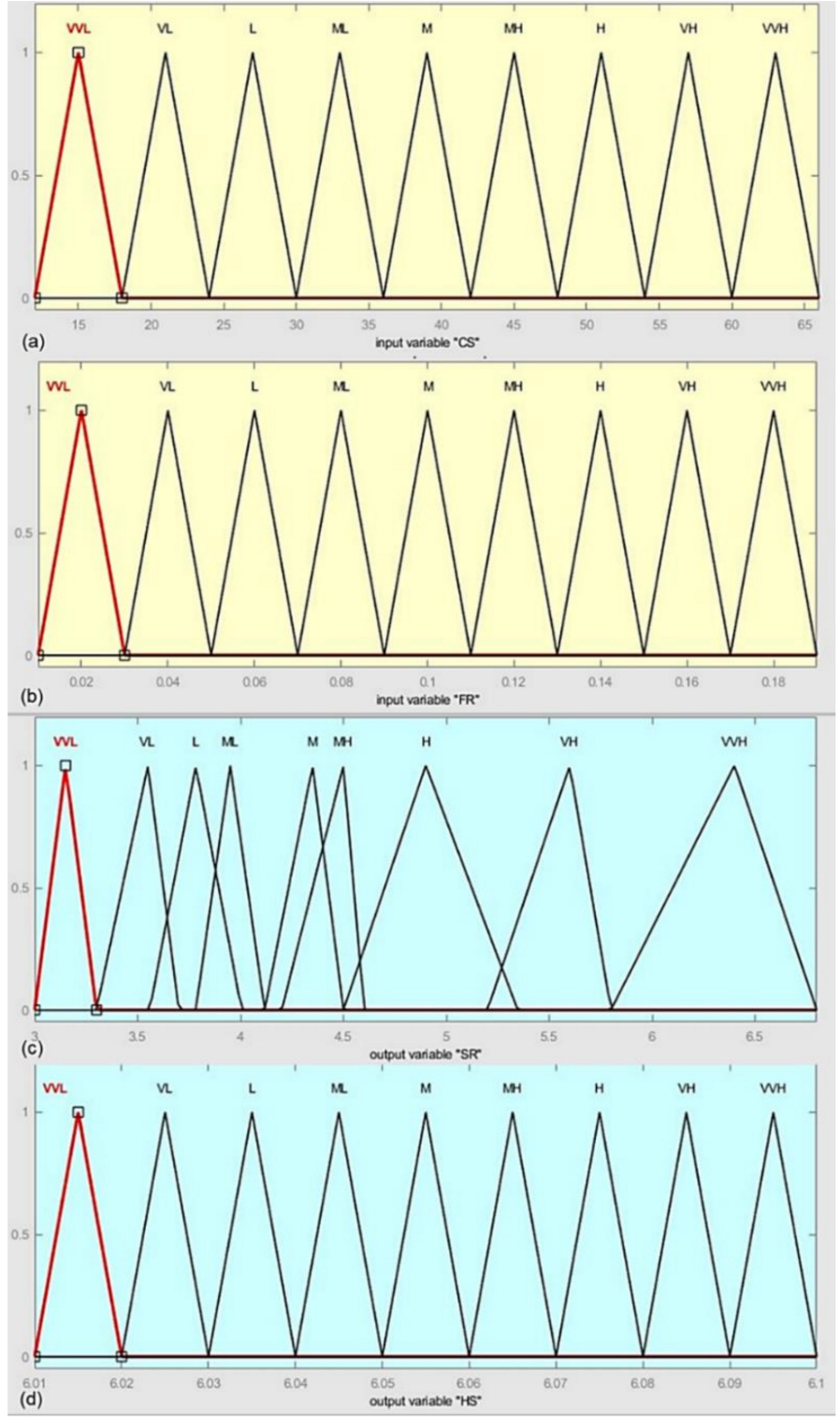

Figure 6. Membership functions: (a) input membership function for cutting speed; (b) input membership function for feed rate; (c) output membership function for surface roughness; (d) output membership function for hole size. 
Table 9. Parameter of fuzzy inference system with membership functions and variables. VVL: very very low, VL: very low, L: low, ML: moderately low, M: medium, $\mathrm{MH}$ : moderately high, $\mathrm{H}$ : high, $\mathrm{VH}$ : very high, $\mathrm{VVH}$ : very very high.

\begin{tabular}{|c|c|c|c|c|c|c|c|c|c|}
\hline \multirow{3}{*}{$\begin{array}{l}\text { Membership } \\
\text { Function Type }\end{array}$} & \multirow{3}{*}{ Variable } & \multicolumn{4}{|c|}{ Fuzzy Input } & \multicolumn{4}{|c|}{ Fuzzy Output } \\
\hline & & \multicolumn{2}{|c|}{ Cutting Speed } & \multicolumn{2}{|c|}{ Feed Rate } & \multicolumn{2}{|c|}{ Surface Roughness } & \multicolumn{2}{|c|}{ Hole Size } \\
\hline & & Parameter & Range & Parameter & Range & Parameter & Range & Parameter & Range \\
\hline \multirow{9}{*}{ Triangular } & VVL & (12 15 18) & (12 66) & $\left(\begin{array}{llll}0.01 & 0.02 & 0.03\end{array}\right)$ & $(0.010 .19)$ & (3 3.153 .3 ) & (3 6.8) & (6.01 6.015 6.02) & (6.01 6.1) \\
\hline & $\mathrm{VL}$ & $(182124)$ & $(1266)$ & (0.03 0.040 .05$)$ & (0.010.19) & (3.3 3.55 3.7) & $(36.8)$ & (6.02 6.025 6.03) & $(6.016 .1)$ \\
\hline & $\mathrm{L}$ & (24 27 30) & $(1266)$ & (0.05 0.060 .07$)$ & $(0.010 .19)$ & $\begin{array}{c}(3.5593 .783 \\
4.005)\end{array}$ & $(36.8)$ & $(6.036 .0356 .04)$ & $(6.016 .1)$ \\
\hline & ML & (30 33 36 & $(1266)$ & $\left(\begin{array}{llll}0.07 & 0.08 & 0.09\end{array}\right)$ & $\left(\begin{array}{llll}0.01 & 0.19\end{array}\right)$ & $\begin{array}{c}(3.7833 .95 \\
4.117)\end{array}$ & $(36.8)$ & $(6.046 .0456 .05)$ & (6.01 6.1) \\
\hline & M & (36 39 42) & (12 66) & (0.09 0.10 .11$)$ & (0.01 0.19] & (4.117 4.354 .5$)$ & (3 6.8] & $(6.056 .0556 .06)$ & (6.01 6.1) \\
\hline & $\mathrm{MH}$ & (42 4548$)$ & $(1266)$ & (0.11 0.120 .13 ) & $\left(\begin{array}{lll}0.01 & 0.19\end{array}\right)$ & $(4.24 .54 .6)$ & $(36.8)$ & $(6.066 .0656 .07)$ & $(6.016 .1)$ \\
\hline & $\mathrm{H}$ & (48 5154$)$ & (12 66) & 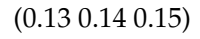 & (0.01 0.19) & (4.5 4.9 5.347) & $(36.8)$ & $(6.076 .0756 .08)$ & (6.01 6.1) \\
\hline & VH & (54 57 60) & (12 66) & (0.15 0.160 .17$)$ & (0.01 0.19) & $(5.25 .65 .8)$ & (3 6.8) & $\left(\begin{array}{l}6.08 \\
6.085\end{array} 6.09\right)$ & (6.01 6.1) \\
\hline & VVH & $(606366)$ & (12 66) & (0.17 0.180 .19$)$ & (0.010.19) & (5.8 6.46 .8$)$ & (3 6.8) & $(6.096 .0956 .1)$ & (6.01 6.1) \\
\hline
\end{tabular}


The developed algorithm was tested on the experimental data of the multi-hole drilling tests for SR and HS. It was found that the algorithm was able to detect all the values at the desired process parameters. The values in the fuzzy set from the developed algorithm behave similarly to the experimental values in which an increase in the drilling parameters increases SR and HS. Table 10 shows that both the experimental data and fuzzy results are consistent with each other and behave similarly for SR and HS. Similarly, a good match is observed in the experimental and modeled values, showing that at high drilling parameters, there is more deviation of the HS from nominal size. In both cases, the percentage error occurs within the range of $10 \%$ for the validation of experimental results. The predicted values are in good agreement with experimental values, which reflects that the obtained fuzzy models present a feasible and effective way for the prediction of SR and HS in a drilling process using a poly-drill head for multi-hole simultaneous drilling.

Table 10. Experimental values and fuzzy results with percentage errors.

\begin{tabular}{ccccccccc}
\hline \multirow{2}{*}{$\begin{array}{c}\text { Hole } \\
\text { Number }\end{array}$} & $\begin{array}{c}\text { Cutting } \\
\text { Speed }\end{array}$ & Feed Rate & \multicolumn{3}{c}{ Surface Roughness } & \multicolumn{3}{c}{ Hole Size } \\
\cline { 4 - 9 } & & $\begin{array}{c}\text { Experimental } \\
\text { Values }\end{array}$ & $\begin{array}{c}\text { Fuzzy } \\
\text { Results }\end{array}$ & \% Error & $\begin{array}{c}\text { Experimental } \\
\text { Values }\end{array}$ & $\begin{array}{c}\text { Fuzzy } \\
\text { Results }\end{array}$ & \% Error \\
\hline 1 & 19 & 0.04 & 3.457 & 3.517 & -1.736 & 6.036 & 6.025 & 0.182 \\
2 & 19 & 0.08 & 3.718 & 3.774 & -1.506 & 6.044 & 6.038 & 0.101 \\
3 & 19 & 0.14 & 4.344 & 4.622 & -6.400 & 6.055 & 6.057 & -0.035 \\
4 & 38 & 0.04 & 3.676 & 3.888 & -5.767 & 6.039 & 6.039 & -0.003 \\
5 & 38 & 0.08 & 4.126 & 4.136 & -0.242 & 6.048 & 6.050 & -0.028 \\
6 & 38 & 0.14 & 4.626 & 4.745 & -2.572 & 6.060 & 6.066 & -0.092 \\
7 & 57 & 0.04 & 4.566 & 4.728 & -3.548 & 6.048 & 6.055 & -0.116 \\
8 & 57 & 0.08 & 4.990 & 4.962 & 0.561 & 6.061 & 6.065 & -0.064 \\
9 & 57 & 0.14 & 5.724 & 5.170 & 9.679 & 6.075 & 6.080 & -0.082 \\
\hline
\end{tabular}

\subsection{Validations of Results}

The validation tests are an essential step for the verification of the results obtained from Taguchi's design approach [38]. Therefore, validation experiments at the optimized process parameters are conducted for SR and HS using a poly-drill head. The average of the validation results is compared with the predicted average based on the Taguchi optimal process parameters and fuzzy logic values. Figure 7 shows that there is a small difference among all the values, and the response optimization predicts the optimum conditions comparatively well.

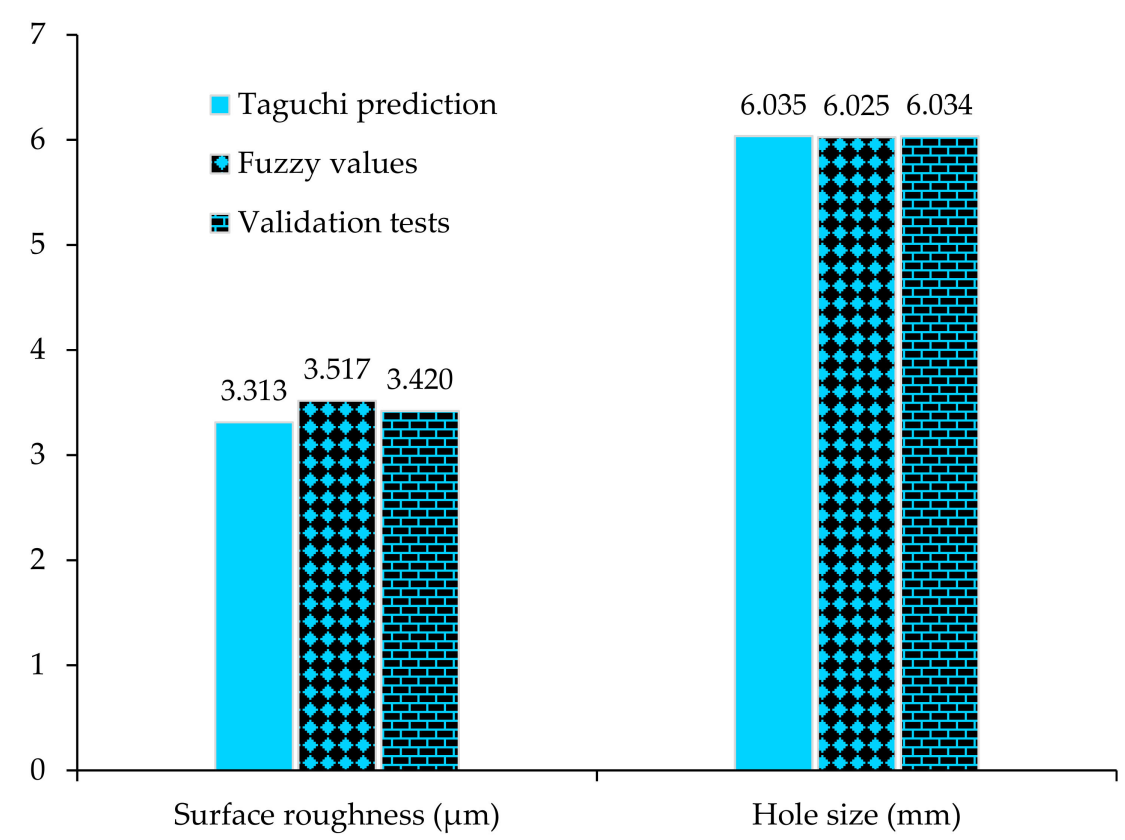

Figure 7. Validation of experimental results for surface roughness and hole size. 


\section{Conclusions}

Optimal machining parameters are essential for high quality drilling of holes, which leads to efficient and effective production. In this work, drilling experiments were performed using one-shot drilling and multi-hole simultaneous drilling with a poly-drill head. The Taguchi method was used for the optimization of process parameters for better hole quality in terms of surface roughness and hole size. Then, regression analysis and ANOVA were applied to confirm the accuracy of the model and the significance of process parameters. Moreover, a fuzzy logic technique was employed for the prediction of surface roughness and hole size in multi-hole drilling using a poly-drill head. The following conclusions are drawn from this work:

- Cutting speed and feed rate in the drilling of Al5083 have a significant impact on both types of drilling process i.e., one-shot drilling and multi-hole drilling. A higher cutting speed generates more heat, which increases the temperature at the hole boundaries, where the chips can easily be clogged over the flutes of the drills. Furthermore, it is speculated that more vibration is likely to be present due to the rotary motion of the tool. In addition, the size of the chips increases with an increase in the feed rate. Therefore, a higher cutting speed and feed rate can affect both the surface roughness and hole size.

- The ANOVA results revealed that for both drilling types, the cutting speed and feed rate are influential on the surface roughness and hole size, respectively. The percent influence of cutting speed on the surface roughness is $40.16 \%$, whereas the feed rate has a $25.02 \%$ contribution. In the case of hole size, the deviation from the nominal drill size is more affected by the feed rate, which has a $61.31 \%$ contribution, and the significance of the cutting speed is $28.72 \%$.

- The Taguchi method was shown to successfully analyze the optimal combination of process parameters for surface roughness and hole size, as achieved in multi-hole drilling with a lower cutting speed and feed rate. Therefore, in comparison to one-shot drilling, a poly-drill head can produce better hole quality and is capable of forming multi-holes simultaneously, which would help in acquiring good productivity even at the lower levels of drilling parameters.

- The fuzzy modeling successfully investigated the surface roughness and hole size in multi-hole drilling. The predicted data is closely correlated to the experimental results with a very small percentage error. Thus, the developed fuzzy model is reliable for the prediction of hole quality at different levels of process parameters, where notable savings in time and cost could be obtained.

- In regression analysis, the values of $\mathrm{R}^{2}$ are more than $80 \%$, which shows that the responses with respect to the machining variables could be easily predicted. The validation experiment reveals that the developed model can be used for predicting better hole quality using a poly-drill head for multi-hole drilling. The average error between each comparison was found to be small and hence, the optimization by the Taguchi method and prediction of values for surface roughness and hole size using fuzzy logic are both acceptable.

Author Contributions: Conceptualization, M.T.-R. and M.A.; methodology, K.G.; software, S.T.; validation, M.A., M.T.-R., K.G., and S.T.; investigation, M.A.; writing-original draft preparation, M.A.; writing-review and editing, M.T.-R., K.G, A.V., and S.T.; supervision, M.T.-R., K.G., and A.V.; funding acquisition, S.T. All authors have read and agreed to the published version of the manuscript.

Funding: China's National Key R\&D Program (No. 2018YFB0803600), National Natural Science Foundation of China (No.61801008), Beijing Natural Science Foundation National (No. L172049), Scientific Research Common Program of Beijing Municipal Commission of Education (No. KM201910005025) sponsored this research in part.

Acknowledgments: The authors would like to thank the technical staff, especially Adrian Davis for his help and support in experiments at the Manufacturing Engineering Lab, School of Engineering, Edith Cowan University, Australia. The first author would also like to thank Edith Cowan University for the awarded (ECU-HDR) higher degree research scholarship.

Conflicts of Interest: The authors declare no conflict of interest. 


\section{References}

1. Neseli, S. Optimization of process parameters with minimum thrust force and torque in drilling operation using Taguchi method. Adv. Mech. Eng. 2014, 6, 925382. [CrossRef]

2. Kurt, M.; Bagci, E.; Kaynak, Y. Application of Taguchi methods in the optimization of cutting parameters for surface finish and hole diameter accuracy in dry drilling processes. Int. J. Adv. Manuf. Technol. 2009, 40, 458-469. [CrossRef]

3. Sun, D.; Lemoine, P.; Keys, D.; Doyle, P.; Malinov, S.; Zhao, Q.; Qin, X.; Jin, Y. Hole-making processes and their impacts on the microstructure and fatigue response of aircraft alloys. Int. J. Adv. Manuf. Technol. 2018, 94, 1719-1726. [CrossRef]

4. Mohan, N.; Ramachandra, A.; Kulkarni, S. Influence of process parameters on cutting force and torque during drilling of glass-fiber polyester reinforced composites. Compos. Struct. 2005, 71, 407-413. [CrossRef]

5. Taguchi, G.K.S.; Konishi, S. Taguchi Methods: Orthogonal Arrays and Linear Graphs. Tools Qual. Eng.; American Supplier Institute: Dearborn, MI, USA, 1987.

6. Hanif, M.I.; Aamir, M.; Ahmed, N.; Maqsood, S.; Muhammad, R.; Akhtar, R.; Hussain, I. Optimization of facing process by indigenously developed force dynamometer. Int. J. Adv. Manuf. Technol. 2019, 100, 1893-1905. [CrossRef]

7. Yang, W.P.; Tarng, Y. Design optimization of cutting parameters for turning operations based on the Taguchi method. J. Mater. Process. Technol. 1998, 84, 122-129. [CrossRef]

8. Vankanti, V.K.; Ganta, V. Optimization of process parameters in drilling of GFRP composite using Taguchi method. J. Mater. Res. Technol. 2014, 3, 35-41. [CrossRef]

9. Ribeiro, J.E.; César, M.B.; Lopes, H. Optimization of machining parameters to improve the surface quality. Proced. Struct. Integr. 2017, 5, 355-362. [CrossRef]

10. Anand, G.; Alagumurthi, N.; Elansezhian, R.; Palanikumar, K.; Venkateshwaran, N. Investigation of drilling parameters on hybrid polymer composites using grey relational analysis, regression, fuzzy logic, and ANN models. J. Braz. Soc. Mech. Sci. Eng. 2018, 40, 214. [CrossRef]

11. Latha, B.; Senthilkumar, V.S. Modeling and Analysis of Surface Roughness Parameters in Drilling GFRP Composites Using Fuzzy Logic. Mater. Manuf. Process. 2010, 25, 817-827. [CrossRef]

12. Aamir, M.; Waqas, M.; Iqbal, M.; Hanif, M.I.; Muhammad, R. Fuzzy logic approach for investigation of microstructure and mechanical properties of Sn96.5-Ag3.0-Cu0.5 lead free solder alloy. Solder. Surf. Mt. Technol. 2017, 29, 191-198. [CrossRef]

13. Tolouei-Rad, M.; Zolfaghari, S. Productivity improvement using special-purpose modular machine tools. Int.J. Manuf. Res. 2009, 4, 219-235.

14. Vafadar, A.; Tolouei-Rad, M.; Hayward, K.; Abhary, K. Technical feasibility analysis of utilizing special purpose machine tools. J. Manuf. Syst. 2016, 39, 53-62. [CrossRef]

15. Aamir, M.; Tolouei-Rad, M.; Giasin, K.; Nosrati, A. Recent advances in drilling of carbon fiber-reinforced polymers for aerospace applications: a review. Int. J. Adv. Manuf. Technol. 2019, 105, 2289-2308. [CrossRef]

16. Meral, G.; Sarıkaya, M.; Mia, M.; Dilipak, H.; Şeker, U. Optimization of hole quality produced by novel drill geometries using the Taguchi S/N approach. Int. J. Adv. Manuf. Technol. 2019, 101, 339-355. [CrossRef]

17. Upputuri, H.B.; Nimmagadda, V.S.; Duraisamy, E. Optimization of drilling parameters on carbon fiber reinforced polymer composites using fuzzy logic. Mater. Today Proc. 2019. [CrossRef]

18. Saravanakumar, A.; Sasikumar, P.; Nilavusri, N. Optimization of Machining Parameters using Taguchi Method for Surface Roughness. J. Mater. Environ. Sci 2016, 7, 1556-1561.

19. Abhishek, K.; Datta, S.; Mahapatra, S.S. Optimization of thrust, torque, entry, and exist delamination factor during drilling of CFRP composites. Int. J. Adv. Manuf. Technol. 2015, 76, 401-416. [CrossRef]

20. Çakıroğlu, R.; Acır, A. Optimization of cutting parameters on drill bit temperature in drilling by Taguchi method. Measurement 2013, 46, 3525-3531. [CrossRef]

21. Azmi, A.I. Design of Fuzzy Logic Model for the Prediction of Tool Performance During Machining of Composite Materials. Proced. Eng. 2012, 38, 208-217. [CrossRef]

22. Rajasekaran, T.; Palanikumar, K.; Vinayagam, B.K. Application of fuzzy logic for modeling surface roughness in turning CFRP composites using CBN tool. Product. Eng. 2011, 5, 191-199. [CrossRef]

23. Kilickap, E. Modeling and optimization of burr height in drilling of Al-7075 using Taguchi method and response surface methodology. Int. J. Adv. Manuf. Technol. 2010, 49, 911-923. [CrossRef] 
24. C. Douglas, M. Design and Analysis of Experiments, 7th ed.; Wiley: New Delhi, India, 2011.

25. Mudhukrishnan, M.; Hariharan, P.; Palanikumar, K. Measurement and analysis of thrust force and delamination in drilling glass fiber reinforced polypropylene composites using different drills. Measurement 2020, 149, 106973. [CrossRef]

26. Rajmohan, T.; Palanikumar, K. Optimization of machining parameters for surface roughness and burr height in drilling hybrid composites. Mater. Manuf. Process. 2012, 27, 320-328. [CrossRef]

27. Davidson, M.J.; Balasubramanian, K.; Tagore, G. Surface roughness prediction of flow-formed AA6061 alloy by design of experiments. J. Mater. Process. Technol. 2008, 202, 41-46. [CrossRef]

28. Giasin, K.; Hodzic, A.; Phadnis, V.; Ayvar-Soberanis, S. Assessment of cutting forces and hole quality in drilling Al2024 aluminium alloy: experimental and finite element study. Int. J. Adv. Manuf. Technol. 2016, 87, 2041-2061. [CrossRef]

29. Kurt, M.; Kaynak, Y.; Bagci, E. Evaluation of drilled hole quality in Al 2024 alloy. Int. J Adv. Manuf. Technol. 2008, 37, 1051-1060. [CrossRef]

30. Giasin, K.; Ayvar-Soberanis, S.; Hodzic, A. An experimental study on drilling of unidirectional GLARE fibre metal laminates. Compos. Struct. 2015, 133, 794-808. [CrossRef]

31. Giasin, K.; Ayvar-Soberanis, S.; French, T.; Phadnis, V. 3D finite element modelling of cutting forces in drilling fibre metal laminates and experimental hole quality analysis. Appl. Compos. Mater. 2017, 24, 113-137. [CrossRef]

32. Zhu, Z.; Guo, K.; Sun, J.; Li, J.; Liu, Y.; Zheng, Y.; Chen, L. Evaluation of novel tool geometries in dry drilling aluminium 2024-T351/titanium Ti6Al4V stack. J. Mater. Process. Technol. 2018, 259, 270-281. [CrossRef]

33. Roukema, J.C.; Altintas, Y. Generalized modeling of drilling vibrations. Part II: Chatter stability in frequency domain. Int. J. Mach. Tool. Manuf. 2007, 47, 1474-1485. [CrossRef]

34. Uddin, M.; Basak, A.; Pramanik, A.; Singh, S.; Krolczyk, G.M.; Prakash, C. Evaluating hole quality in drilling of Al 6061 alloys. Mater. 2018, 11, 2443. [CrossRef] [PubMed]

35. Zerti, A.; Yallese, M.A.; Zerti, O.; Nouioua, M.; Khettabi, R. Prediction of machining performance using RSM and ANN models in hard turning of martensitic stainless steel AISI 420. Proc. Inst. Mech. Eng. Part C J. Mech. Eng. Sci. 2019, 233, 4439-4462. [CrossRef]

36. Vinayagamoorthy, R.; Manoj, I.; Kumar, G.N.; Chand, I.S.; Kumar, G.S.C.; Kumar, K.S. A central composite design based fuzzy logic for optimization of drilling parameters on natural fiber reinforced composite. J. Mech. Sci. Technol. 2018, 32, 2011-2020. [CrossRef]

37. Pedrycz, W. Fuzzy equalization in the construction of fuzzy sets. Fuzzy Set. Syst. 2001, 119, 329-335. [CrossRef]

38. Ross, P.J. Taguchi techniques for quality engineering: loss function, orthogonal experiments, parameter and tolerance design; McGraw-Hill: New York, NY, USA, 1988. 